\title{
Dry matter intake - a generic approach to predict the transfer of radiocaesium to ruminants?
}

\author{
N.A. Beresford, R.W. Mayes ${ }^{1}$, C.L. Barnett and C.S. Lamb ${ }^{1}$ \\ Centre for Ecology \& Hydrology. CEH Meriewood, Windermere Rd., Grange-over-Sands, \\ Cumbria LA11 6JU, U.K. \\ ${ }^{1}$ Macaulay Land Use Research institute, Craigiebuckler, Aberdeen AB15 8QH, U.K.
}

\begin{abstract}
We have previously demonstrated a relationship between dry matter (DM) intake and the degree of transfer of radiocaesium to the muscle of adult sheep. Here, we present the results of an experiment during which we examined the effect of lamb growth and protein turnover rates, brought about by controlling feed DM intakes, on radiocaesium transfer and turnover. Lambs with high DM intakes and, as a consequence, high rates of growth, had a lower mean radiocaesium transfer coefficient from the diet to muscle than lambs with lower intake and growth rates. Furthernore, high rates of dry matter intake decreased the biological half-life of radiocaesium from muscle. The administration of $\left[{ }^{35} \mathrm{~S}\right]$-methionine to the study lambs enables us to suggest that radiocaesiltm transfer may be related to protein turnover.

When the results were compared with those of other studies using sheep, a consistent relationship between DM intake and radiocaesium transfer across all animals regardless of age or physiological status was observed. Extrapolation of the relationship to DM intake rates appropriate to cattle predict radiocaesium transfer coefficients in broad agreement with reported values.
\end{abstract}

\section{INTRODUCTION}

Over recent years it has been acknowledged that the transfer of radiocaesium to animals is influenced by many factors some of which have been studied in comparative detail (see review by Ref. [1]). In a previous study, we demonstrated a relationship between the dry matter intake of adult sheep and the transfer of radiocaesium to their muscle [2]. The feeding levels of young animals may vary considerably and can be used to manipulate growth rate. Here, we describe a study designed to evaluate the impact of feeding level and growth rate on the dynamics of radiocaesium in growing lambs. The hypothesis that radiocaesium transfer may be influenced by protein metabolism is also investigated.

\section{MATERIALS \& METHODS}

\subsection{Period 1}

Twenty-four, approximately 6 month old Scottish Blackface lambs were placed into individual indoor pens and allocated to one of two experimental treatments designed to achieve either a high or low growth rate respectively. The animals allocated to the two treatments were balanced as far as possible with regard to initial live-weight and sex. Feeding levels were set, according to ARC [3], to achieve growth rates of $0.05 \mathrm{~kg}$ $\mathrm{d}^{-1}$ (low growth rate) and $0.20 \mathrm{~kg} \mathrm{~d}^{-1}$ (high growth rate). The experimental diet was a dried pelleted feed based on grass meal and sugar beet pulp (Green Keil, North Eastern Farmers Ltd., Aberdeen).

Four days after being introduced to the experimental diet, the lambs were each administered circa $2 \mathrm{M}$ $\mathrm{Bq}$ of $\left[{ }^{35} \mathrm{~S}\right]$-methionine (Amersham International) by intravenous injection. Seven days later, twice-daily oral administration of a paper pellet containing circa $5200 \mathrm{~Bq}$ of ${ }^{137} \mathrm{Cs}$ was begun. Caesium-137 administration continued for a period of 15 days. 
Caesium-137 activity concentrations in hind-leg muscle were determined by live-monitoring on 1, 2, 3, $4,5,6,7,9,11,13$ and 15 days after commencing ${ }^{137} \mathrm{Cs}$ administration; measurements were also made the day prior to beginning ${ }^{137} \mathrm{Cs}$ administration. Live-monitoring was conducted using a $76 \mathrm{~mm} \mathrm{NaI}$ detector linked to a Canberra series $20 \mathrm{MCA}$; count times were sufficient to achieve a error of $5 \%$ on the peak area. The detector had been calibrated against muscle samples removed from animals previousiy live-monitored and subsequently analysed on hyper-pure Ge detectors. $A^{137} \mathrm{Cs}$ standard, of approximately $30 \mathrm{kBq}$, was counted at frequent intervals on each measurement day to determine the efficiency of the detector. Background radiocaesium levels were determined by monitoring a lamb of similar size, which was not being administered ${ }^{137} \mathrm{Cs}$.

Urine samples were collected 7,14 and 21 days after $\left[{ }^{35} \mathrm{~S}\right]$-methionine administration by placing each animal in a metabolism cage, equipped with a collection chute and separator to prevent faecal contamination of urine, for a period of a few hours. Urine samples were acidified with $\mathrm{HNO}_{3}$, barium chloride solution added and the resultant $\mathrm{BaSO}_{4}$ precipitate was washed with water and dried. The dried precipitate was decolourised by heating with $\mathrm{H}_{2} \mathrm{O}_{2}$ and the ${ }^{35} \mathrm{~S}$ activity concentration determined by suspension counting using 4\% fumed silica (Cab-o-Sil) in Instaflor scintillant (Canberra Packard); the count time was terminated at a $\sigma$ value of $1 \%$. Activity concentrations were decay-corrected to the day of administration.

\subsection{Period 2}

Caesium-137 administration was stopped after 15 days and the lambs within each treatment were reallocated, such that six animals within each treatment remained on the same treatment and six changed to the other growth rate feeding level. Consequently there were four treatments: (i) $H-H$, high growth rate diet during both study periods; (ii) $H-L$, high growth rate diet in Period 1 and low growth rate diet in Period 2; (iii) $L-L$, low growth rate diet during both study periods; (iv) $L-H$, low growth rate diet in Period 1 and high growth rate diet in Period 2. The lambs were fed according to these dietary treatments for a further 15 days. Caesium-137 activity concentrations were determined in hind-leg muscle by live-monitoring 1, 2, 3, 4, 5, 6, $7,9,11,13$ and 15 days after ceasing ${ }^{137} \mathrm{Cs}$ administration.

The lambs were weighed at five-day intervals throughout both periods of the study.

\section{RESULTS}

\subsection{Period 1}

Dry matter intake (DMI), live-weight (LWt) and LWt-change data are summarised in Table 1; mean values were significant different between treatments for all parameters $(p<0.001)$. The ${ }^{137} \mathrm{Cs}$ activity concentration in the muscle of lambs fed to obtain a high growth rate was significantly lower $(p<0.001)$ after $15 \mathrm{~d}$ of ${ }^{137} \mathrm{Cs}$ administration than that of lambs fed to obtain a low growth rate (Figure 1; Table 1). Caesium-137 transfer coefficients $\left({ }^{137} \mathrm{Cs} \mathrm{Bq} \mathrm{kg}{ }^{-1}\right.$ in muscle : $\mathrm{Bq} \mathrm{d} \mathrm{d}^{-1}$ administered) at equilibrium were estimated by fitting exponential relationships to the live-monitoring data for each animal (Table 1); the fitted relationships were significant $(\mathrm{p}<0.01$ ) and explained $>90 \%$ of the observed variability.

Urine samples were successfully collected on the three sampling occasions from all but four lambs. The mean activity of ${ }^{35} \mathrm{~S}$ per gram of urinary sulphate was significantly higher $(\mathrm{p}<0.01)$ for lambs receiving the low growth rate diet compared with those receiving the high growth rate on all three measurement occasions; declining from a factor of 2 to 1.75 during the course of the study. The rate of decline of ${ }^{35} \mathrm{~S}$ activity concentrations in urine was estimated as the slope of a linear regression fitted to data for each animal; estimates were not made for those animals for which less than three samples were obtained. The linear regressions had $R^{2}$ values in the range 0.42 to 0.99 and were all significant $(p<0.05)$. The mean rate of reduction in ${ }^{35} \mathrm{~S}$ activity concentrations in the urine of lambs on the low growth rate diet was more than two fold higher than that estimated for the high growth rate animals $(\mathbf{p}<0.001)$ (Table 1). 
Significant correlations ( $\mathrm{p}<0.00 \mathrm{I}$ ) were observed between the ${ }^{137} \mathrm{Cs}$ activity concentration in muscle and LWt $(R=-0.87)$, DMI $(R=-0.87)$, LWt-change $(R=-0.79)$ and rate of ${ }^{35} \mathrm{~S}$ reduction in urine $(R=-0.75)$.

Table 1: Summary of animal performance parameters, ${ }^{137} \mathrm{Cs}$ activity concentrations in muscle after $15 \mathrm{~d}$, estimated equilibrium transfer coefficient $\left(F_{f}\right)$ and the rate of change in ${ }^{35} \mathrm{~S}$ activity concentuations in urine for Period 1.

\begin{tabular}{lcccc}
\hline Parameter & \multicolumn{2}{c}{ High growth rate } & \multicolumn{2}{c}{ Low growth rate } \\
& Mean \pm SD & Range & Mean \pm SD & Range \\
\hline LWt $(\mathrm{kg})$ & $36 \pm 1.9$ & $34-40$ & $30 \pm 3.0$ & $26-35$ \\
LWt-change $(\mathrm{kg})$ & $2.8 \pm 0.87$ & $1.0-3.5$ & $0.2 \pm 0.58$ & $-1.0-1.0$ \\
DMI $\left(\mathrm{kg} \mathrm{d}^{-1}\right)$ & $1.34 \pm 0.235$ & $0.660-1.590$ & $0.67 \pm 0.056$ & $0.59-0.76$ \\
$137 \mathrm{Cs}\left(\mathrm{Bq} \mathrm{kg} \mathrm{kg}^{-1}\right)$ & $2600 \pm 370$ & $1900-3200$ & $3900 \pm 450$ & $3400-4600$ \\
Equilibrium $\mathrm{F}_{\mathrm{f}}\left(\mathrm{d} \mathrm{kg}^{-1}\right)$ & $0.27 \pm 0.044$ & $0.19-0.34$ & $0.45 \pm 0.064$ & $0.34-0.58$ \\
Rate of change in & $-6.3 \pm 1.88$ & $-9.7--3.1$ & $-14 \pm 2.3$ & $-18--11$ \\
urinary ${ }^{35}{\mathrm{~S}\left(\mathrm{Bg} \mathrm{g}^{-1} \mathrm{~d}^{-1}\right)}$ & & & \\
\hline
\end{tabular}

\subsection{Period 2}

Animal performance data are summarised in Table 2 . The change in the mean ${ }^{137} \mathrm{Cs}$ activity concentrations in the muscle of the four study treatments is shown in Figure 1 . The data for individual lambs were best described by single exponential relationships $\left(R^{2}=0.65-0.93 ; p<0.01\right)$. There were significant differences in the resultant biological half-life $\left(\mathrm{T}_{1 / 2 \mathrm{~b}}\right)$ estimates for ${ }^{137} \mathrm{Cs}$ in muscle (Table 2) in the order: $H-L>L-L \approx H-H$ $>L-H$. Biological half-life was significantly $(\mathrm{p}<0.01)$ correlated with $\mathrm{LWt}$-change $(\mathrm{R}=-0.58)$ and $\mathrm{DMI}(\mathrm{R}=-$ $0.53)$.

Table 2: Summary of animal performance parameters and the biological half-life of ${ }^{137} \mathrm{Cs}$ in hind-leg muscle for Period 2.

\begin{tabular}{|c|c|c|c|c|c|c|c|c|}
\hline \multirow[t]{2}{*}{ Parameter } & \multicolumn{2}{|c|}{$H-H$} & \multicolumn{2}{|c|}{$H-L$} & \multicolumn{2}{|c|}{$\overline{L-L}$} & \multicolumn{2}{|c|}{$L \cdot H$} \\
\hline & MeantSD & Range & MeantSD & Range & $\operatorname{Mean} \pm S D$ & Range & MeantSD & Range \\
\hline LW! (kg) & $39 \pm 2.4$ & $36 \cdot 44$ & $36 \pm 2.3$ & $34-40$ & $32 \pm 3.8$ & $26 \cdot 37$ & $35 \pm 2.9$ & 30.38 \\
\hline $\begin{array}{l}\text { LWt change } \\
(\mathrm{kg})\end{array}$ & $2.4 \pm 1.53$ & $0.5-5.0$ & $0.8 \pm 1.13$ & $-0.5-2.5$ & $1.0 \pm 0.32$ & $0.5-1.5$ & $3.8 \pm 1.17$ & $2 \cdot 5$ \\
\hline DMI $\left(\mathrm{kg} \mathrm{d}^{-1}\right)$ & $1.41 \pm 0.126$ & $1.27 \cdot 1.59$ & $0.81 \pm 0.212$ & $0.69-1.24$ & $0.67 \pm 0.060$ & $0.59-0.76$ & $1.31 \pm 0.117$ & $1.2 \cdot 1.5$ \\
\hline $\mathrm{T}_{1 / 2 \mathrm{~b}}$ (d) & $16 \pm 0.7$ & $15-17$ & $24 \pm 1.6$ & $22-27$ & $18 \pm 1.7$ & $15-19$ & $13 \pm 1.4$ & $11 \cdot 14$ \\
\hline
\end{tabular}

\section{DISCUSSION}

\subsection{Effect of feeding level on radiocaesium uptake and turnover by lambs}

There was a significant effect of feeding level on the transfer of ${ }^{137} \mathrm{Cs}$ to the muscle of study lambs and subsequently on the rate of loss of ${ }^{137} \mathrm{Cs}$. Whilst the feeding levels resulted in different growth rates, the observed lower ${ }^{137} \mathrm{Cs}$ transfer to lambs on the higher feeding level is not the result of growth dilution. Transfer coefficients estimated for lambs receiving the low growth rate diet were 1.7 times higher than those receiving the high growth rate diet; however, the weight gained by the higher growth rate lambs was only 8 $\%$ of their initial live-weight. Both DMI and LWt explained $76 \%$ of the variation in the transfer of radiocaesium to muscle; this is discussed further below.

There was an effect of changing dietary regime on the ${ }^{337} \mathrm{Cs} \mathrm{T}_{1 / 2 \mathrm{~b}}$, changing from a high to low growth DMI reducing the rate of reduction in muscle ${ }^{137} \mathrm{Cs}$ activity concentrations whilst increasing DMI reduced $T_{1 / 2 b}$. It is therefore possible that manipulation of dietary intake could be used as a countermeasure to 
increase the rate of reduction in ${ }^{137} \mathrm{Cs}$ activity concentrations in meat. Moreover caution should be taken not to reduce the DMI of animals during periods of clean feeding.

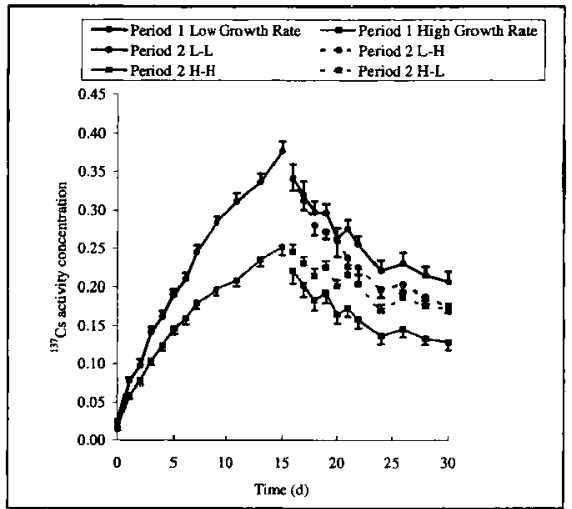

Figure 1: Change in the mean (土SE) ${ }^{137} \mathrm{Cs}$ activity concentration in hind-leg muscle of lambs within the different experimental treatments as determined by live-monitoring; results have been normalised to the daily rate of ${ }^{137} \mathrm{Cs}$ administration.

\subsection{Protein turnover rate and radiocaesium transfer}

Whilst the intravenous administration of $\left[{ }^{35} \mathrm{~S}\right]$-methionine to the study lambs does not allow us to make absolute estimates of protein turnover rate, it should give an indication of differences in protein turnover between animals. Much of the intravenously administered $\left[{ }^{35} \mathrm{~S}\right]$-methionine should be rapidly incorporated into body protein with most of the remaining ${ }^{35} \mathrm{~S}$ being excreted as sulphate. By administering $\left.{ }^{35} \mathrm{~S}\right]-$ methionine 7 days prior to the first urine collection the effects of pools with a rapid turnover (e.g. sulphate) should have been minimal. Thus, the rate of decline in the specific activity of ${ }^{35} \mathrm{~S}$ in urinary sulphate should represent an index of protein rate.

The observed relationship between the rate of loss of ${ }^{35} \mathrm{~S}$ in urine and ${ }^{137} \mathrm{Cs}$ activity concentrations in muscle $\left(\mathrm{R}^{2}=0.56\right)$ suggests that protein metabolism is possibly a controlling mechanism determining radiocaesium uptake. We also observed that the rate of decline in the specific activity of ${ }^{35} \mathrm{~S}$ in urine was negatively correlated with DMI $(R=0.75 ; \mathrm{p}<0.001)$, and that the specific activity of ${ }^{35} \mathrm{~S}$ in urinary sulphate was higher for animals on the low growth rate treatment. The synthesis, degradation and deposition of protein have been shown to increase with dietary intake $[4,5]$. Therefore, if there is an influence of protein turnover rate on radiocaesium dynamics, as suggested by our ${ }^{35} \mathrm{~S}$ results, we would expect that changes in DMI would influence radiocaesium retention $\left(\mathrm{F}_{t}\right)$ and loss $\left(\mathrm{Tl} / \mathrm{2}_{\mathrm{b}}\right)$ as we observed. However, it is difficult to be conclusive with regard to exactly what mechanisms of protein turnover the ${ }^{35} \mathrm{~S}$ results reflect. For example, the rate of decline in ${ }^{35} \mathrm{~S}$ specific activity concentrations could suggest a greater degree of protein degradation compared to synthesis at lower rates of $\mathrm{DMI}$; the lower ${ }^{35} \mathrm{~S}$ specific activities determined in urine of the animals receiving a higher rate of DMI may signify a greater dilution with stable $S$ representing the degradation of more recently synthesised protein. 


\subsection{Generic relationship between $F_{f}$ and DMI}

Recently, Nalezinski et al. [6] derived expressions between live-weight and radiocaesium transfer coefficients from a (limited) compilation of literature data. Separate expressions were derived for ruminants $\left(F_{f}=1.9 \mathrm{LWt} \mathrm{t}^{-0.72}\right)$ and monogastrics, comprising hens and pigs $\left(F_{f}=5.8 \mathrm{LWt}{ }^{-0.70}\right)$. A similar relationship $\left(\left(F_{f}=\right.\right.$ $8.89 \mathrm{LWt}^{-0.73}$ ) was derived for mammals by Macdonald [7]. Whilst we observed a relationship between $F_{f}$ and LWt in this study, in a previous study of adult ewes receiving ad libitum levels of feed no relationship between radiocaesium $F_{f}$ and live-weight was observed [2]. However, in both studies we determined a relationship between $F_{f}$ and $D M I$.

The benefit of trans-species relationships such as those suggested by Nalezinski et al. and Macdonald are obvious. We have over 140 measurements of the transfer of radiocaesium to the muscle of sheep conducted under controlled conditions similar to those described here. These comprise: (i) ad libitum fed ewes [2]; (ii) ewes carrying single or twin lambs [8]; (iii) ewes suckling single or twin lambs [8]; (iv) ewes fed to maintenance and above maintenance levels [8]; lambs fed to achieve different growth rates as described in this paper. Combining these data no relationship between $F_{f}$ and $L W t$ is observed $\left(R^{2}=0.04\right)$. However, as demonstrated in Figure 2, there is a significant $\left(R^{2}=0.82 ; p<0.01\right)$ relationship between $F_{r}$ and DMI described by the equation: $\mathbf{F}_{\mathrm{f}}=9.64 \mathrm{DMI}^{-0.50}$.

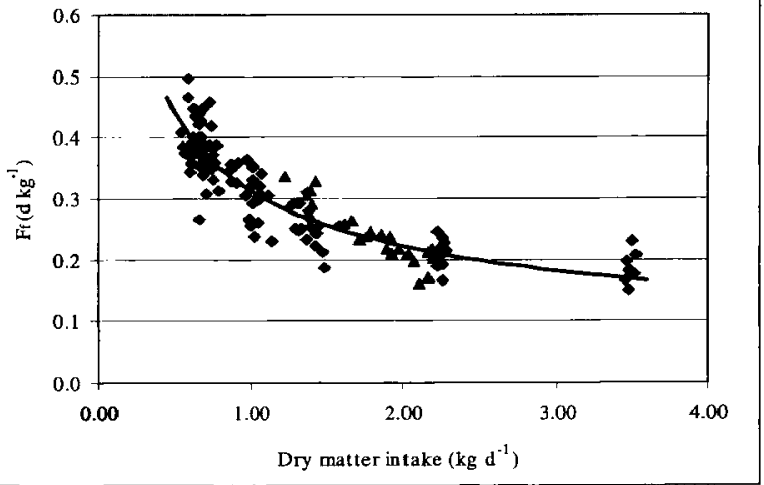

Figure 2: Relationship between radiocaesium $\vec{F}_{\mathrm{f}}$ and DMI. Data includes lambs from this study $(\boldsymbol{\bullet})$, ad libitum fed ewes ( $\boldsymbol{\Delta}$ ) [2], lactating ewes, pregnant ewes and ewes fed to different levels relative to maintenance requirements $(\bullet)$ [8].

Relationships between $\mathbf{F}_{\mathrm{f}}$ and $\mathrm{LWt}$ may be generally applicable across species for a particular source of radiocaesium. However, they do not account for variation in $F_{f}$ observed as a consequence of physiological factors such as growth or lactation. Figure 2 includes sheep of different ages, feeding regime and physiological condition receiving ionic radiocaesium. It demonstrates that DMI may be a better predictor of $F_{f}$ than LWt. We acknowledge that to date this is based upon data from a number of our own studies. However, if we use a DMI of $7.2 \mathrm{~kg} \mathrm{~d}^{-1}$, the IAEA recommended value for beef cattle [9], we predict a radiocaesium transfer coefficient of $0.12 \mathrm{~d} \mathrm{~kg}^{-1}$ from the relationship in Figure 2. This compares with a recommended value of $0.05 \mathrm{~d} \mathrm{~kg}^{-1}$ (note the live-weight relationship of Nalezinski $e t$ al . predicts an $F_{f}$ of 0.02 $\mathrm{d} \mathrm{kg}^{\mathbf{l}}$ ). Although there is some discrepancy between the predicted and recommended values, agreement is good enough to suggest that further investigation of a generic relationship for ruminants between 
radiocaesium $F_{f}$ and DMI is warranted. The dependence of transfer coefficient on dry matter intake may be especially important for dairy animals as their DMI will vary considerably during the course of lactation. Recently it has been observed that transfer coefficients recommended on the basis of western European and North American data under predicted the transfer of radiocaesium to cattle in the former Soviet Union where DMI values are comparatively low [10].

Whilst we have speculated about the influence of the relationship between DMI and protein on radiocaesium turnover above, we cannot be certain of the mechanism of the relationship demonstrated in Figure 2. Higher DMI's lead to a faster gut passage time [11] prompting the suggestion that absorption of radiocaesium in the gut may be reduced. However, in a previous study we found that the influence of DMI on radiocaesium absorption in sheep was minimal [2] and similar absorption values have been determined for radiocaesium for sheep in a large number of studies and also dairy cattle [12]. An increase in cellular metabolism with increasing food intake has previously been observed, the activity of $\mathrm{Na}+, \mathrm{K}+-\mathrm{ATPase}$ varying with food intake [4]; such an effect could influence the movement of Cs across cell membranes.

\section{Acknowledgements}

The work described within this paper was funded under the $3^{\text {tr }}$ Framework Programme of the European Commission (contract number Fl3PCT920006). The authors are grateful to Dan Galeriu (National Institute for Nuclear Physics and Engineering, Romania) for discussions during the preparation of this paper.

\section{References}

[1] Howard B.J. and Beresford N.A., Advances in animal radioecology. In: Radioactive pollutants: impact on the environment and humans, Brechignac F. and Howard B.J. Eds. (EDP Sciences, Les Ulis, 2001) pp. 187-207.

[2] Beresford N.A., Mayes R.W., Barnett C.L., MacEachem P.J. and Crout N.M.J., Radiation \& Environ. Biophys. 37 (1998) 277-281.

[3]Agricultural Research Council, The nutrient requirements of numinant livestock (C.A.B. International Wallingford, 1980).

[4] Blaxter K., Energy metabolism in animals and man (Cambridge University Press, Cambridge, 1989).

[5] Saggau E., Schadereit R., Beyer M., Susenbeth A., Voigt J. and Hagemeister H., J. Anim. Physiol. A. Anim. Nutr. 84 (2000) 29-42.

[6] Nalezinski S., Rühm W. and Wirth, E., Hlth. Phys. 70 (1996) 717-721.

[7] Macdonald C.R., Ingestion rates and radionuclide transfer in birds and mammals on the Canadian Shield (Atomic Energy of Canada Ltd., Pinawa, 1996).

[8] Howard B.J., Assimakopoulos P.A., Crout N.M.J., Mayes R.W., Voigt G., Vandecasteele C.M., Zelenka J., Hove $\mathbf{K}$. and Hinton T., Transfer of radionuclides in animal production systems. (Institute of Terrestrial Ecology, Grange-over-Sands, 1995).

[9] International Atomic Energy Agency, Handbook of transfer parameter values for the prediction of radionuclide transfer in temperate environments. (IAEA, Vienna, 1994).

[10] Beresford N.A., Voigt G., Wright S.M., Howard B.J., Barnett C.L., Prister B., Balonov M., Ratnikov A., Travnikova I., Gillett, A.G., Mehli H., Skuterud L., Lepicard S., Semiochkina N., Perepeliantnikova L., Goncharova N. \& Arkhipov A.N., J. Environ. Radioactivity, 56 (2001) 215-239.

[11] Faichney G.J., The kinetics of particulate matter in the rumen, Control of digestion and metabolism in ruminants: Proceedings of the 6th International Symposium on Ruminant Physiology, Banf, 10-14 ${ }^{\text {th }}$ Sept. 1984, Milligan L.P., Grovum W.L. and Dobson A. Eds. (Prentice-Hall, Eaglewoood Cliffs NJ, 1986) pp. 173-195.

[12] Beresford N.A., Mayes R.W., Cooke A.I., Bamett C.L., Howard B.J., Lamb C.S. and Naylor G.P.L., Environ. Sci. \& Techol. 34 (2000) 4455-4462. 